\title{
LEGAL ASPECTS OF CHANGES IN THE FIELD OF AIR TRAFFIC IN THE CONTEXT OF PREPARING UKRAINE FOR THE ENTRY INTO A SINGLE EUROPEAN SKY
}

Summary. In compiling this article, attention is focused on the analysis of Ukrainian legislation regarding air transportation and comparing it with European regulations, highlighting the main problems, opportunities and ways of improving. The positive and negative aspects of the common aviation space between Ukraine and the EU, as well as the prospects for the implementation of the transport strategy of Ukraine, were investigated and disclosed. The article proves the necessity of concluding the Agreement between Ukraine and the EU on the Common Aviation Area (SAP), which will facilitate the harmonization of legislation in the field of civil aviation, industrial cooperation and the gradual liberalization of markets. The article concludes that the process of harmonizing national and European standards and norms, as well as the establishment of the "open sky" regime in the European airspace, is a long-term, requires considerable effort, as well as a large number of measures by the state.

Keywords: integration process, International Civil Aviation Organization(ICAO), European Common Aviation Area (ECAA), Single European Sky, liberalization, CAA Agreement.

Мудрик В.В., Шевченко Ю.В. Національний авіаційний університет

\section{ПРАВОВІ АСПЕКТИ ЗМІН У СФЕРІ ПОВІТРЯНИХ ПЕРЕВЕЗЕНЬ В КОНТЕКСТІ ПІДГОТОВКИ УКРАЇНИ ДО ВСТУПУ В ЄДИНЕ ЄВРОПЕЙСЬКЕ НЕБО}

Анотація. Складаючи цю статтю, увага зосереджувалася на аналізі українського законодавства щодо повітряних перевезень та порівнянні його з европейськими нормативними актами, з висвітленням основних проблем, можливостей та шляхів вдосконалення. Досліджено та розкрито позитивні та негативні сторони спільного авіаційного простору між Україною і ЄС, а також перспективи процесу реалізації транспортної стратегії України. У статті розкриваються проблемні питання щодо становлення режиму «відкритого неба" в европейському повітряному просторі. Розглянуто шлях поступової і поетапної інтеграції суверенних європейських повітряних сполучень в єдиний европейський повітряний простір. У статті доведена необхідність укладення Угоди між Україною та СС про Спільний авіаційний простір (САП), що сприятиме гармонізації законодавства у сфрері цивільної авіації, промислового співробітництва та поступового лібералізація ринків. Також розглянуто заходи, що були здійснені для сприяння укладання Угоди про САП та аналізовано інтереси чиїх сторін задіяні для цього. Було запропоновано ряд заходів щодо змін до Повітряного кодексу України, що може допомогти прискорити процес інтеграції та поліпшити чинне законодавство. Також, для того щоб вирішити проблему відсутності прогресу у підписанні Угоди про спільний авіаційний простір та лібералізації ринку повітряного транспорту, пропонуються наступні альтернативи та їх детальний опис: збільшення політичного тиску з боку України щодо підписання Угоди про САП, зміна підходу до переговорів щодо підписання Угоди, проведення переговорів на користь Угоди без її безпосереднього підписання, та зосередження уваги на реалізації першого етапу Угоди. В роботі зроблено висновок, що процес узгодження національних та загальноєвропейських стандартів і норм, а також становлення режиму "відкритого неба" в европейському повітряному просторі є довготривалим, вимагає значних зусилль, а також велику кількість заходів з боку держави та проявляється як в позитивних так $\mathrm{i}$ негативних наслідках, які потребують ретельного розгляду та аналізу.

Ключові слова: інтеграційний процес, Міжнародна організація цивільної авіації (ІКАО), Свропейський Спільний Авіаційний Простір, Єдине небо Свропи, лібералізація, Угода про САП.

$\mathrm{T}$ he transport infrastructure should be developed at a fast pace in order to promote the rapid economic and social development of the country, taking into account national needs and interests. Nowadays integration processes in the foreign policy of Ukraine have become significantly more active, it becomes necessary to bring about the legal regulation of Ukraine, namely national legislation, to those international standards that are common to all countries of the world.

In particular, in the State Program for Adaptation of ukrainian legislation to the Legislation of the European Union, approved by the Law of Ukraine dated March 18, 2004 No. 1629-IV, among the priority areas in which the legislation of Ukraine is being adapted is, in particular, the sphere of transport, as well as bringing the regulatory framework governing the activities of Ukrainian civil aviation in line with the requirements of the International Civil Aviation Organization.

That is why the current issue for Ukraine now is the conclusion of the Agreement between Ukraine and the EU on European Common Aviation Area (ECAA), which will contribute to the harmonization of legislation in the field of civil aviation, industrial cooperation and gradual liberalization of markets.

The existence of the CAA is ensured on the basis of comprehensive agreements between the EU and third countries in the field of air transport. Similar agreements were concluded by the EU with Albania, Bosnia and Herzegovina, the Republic of Macedonia, Montenegro, Serbia, Kosovo, Norway, Iceland, Liechtenstein, Switzerland, Morocco, Georgia, Israel, Jordan and Moldova and so on. 
Ukraine has repeatedly declared its desire to join the initiative of the Single European Sky. However, the Agreement is not signed yet. Negotiations about the conclusion of an agreement between Ukraine and the EU that deal with CAA began in 2007. The initialling of the CAA Agreement was held on November 28, 2013 in Vilnius at the Ukraine-EU summit. The signing of the Agreement on CAA has been postponed since 2013, despite the officially announced readiness of the Ukrainian side. The main reason for postponing the signing of this Agreement is the lack of consensus between Spain and the United Kingdom regarding the wording of paragraph 31 "Territory" of Article 2 "Definition" of the Agreement with regard to the territorial status of Gibraltar [1].

Thus, bilateral air agreements with all EU member states concerning air traffic and a horizontal agreement with the European Commission on certain aspects of air traffic (December 2005) remain the basis of contractual relations between Ukraine and the EU. Although the relevant Agreements allow airlines to operate flights between any EU member state and Ukraine, most of them provide for restrictions on the number of routes, flights and air carriers intended.

The CAA Agreement is incredibly important for Ukraine as it guarantees the provision of full access to the air transportation market without restrictions in the designation of carriers, routes, rights, capacity, frequency, tariffs and code sharing. "Open Skies" aims at the unification of the air transport markets of Ukraine and the EU, which will contribute to more efficient use of the air transportation market and improve service quality, develop the transit potential of Ukraine, integrate Ukraine into European aviation structures and strengthen the country's authority as an aviation European state.

The main idea of the CAA agreement is to change the Ukrainian safety rules in aviation in accordance with European standards. In practice, the agreement will allow European companies to fly without restrictions to any airports in Ukraine, and to fly to any airports in Europe for Ukrainian air carriers. For ordinary people, this means that all European low-cost airlines will work in Ukraine, which will significantly reduce the price of air travel and increase their number and directions [2].

Evaluating the map below, the difference between the number of flights in Ukraine and Europe can be assessed.

State Aviation Administration of Ukraine is continuing the preparation of the CAA Agreement. The basis of work related to the integration into European and world transport systems is the introduction of European norms and standards in the air transport sector, adherence to international conventions and agreements, development of infrastructure, international transport corridors and check points, as well as ensuring safety and environmental transportations. Therefore, it is necessary to harmonize the Ukrainian air transport network in accordance with European standards on the basis of not declarative, but real implementation of state target programs.

"Open Skies" is the path to the development of regional airports, passenger and freight traffic that will fill the sky over Ukraine with airplanes. The accession of Ukraine to the EU aviation space will lead to a large number of tangible benefits, such as:

1. Improvement of the service quality and level of flight safety.

2. An increase in the supply of passenger air transportation services and, as a result, a decrease in it prices.

3 . The loading of regional airports in Ukraine and the harmonious development of the transit potential of the Boryspil airport,

4. Improvement of air links between the Ukrainian regions and the EU countries - facilitating the emergence of new markets for products of Ukrainian origin, and in particular, the aviation industry.

6. Attraction of investments in aviation infrastructure, increasing the number of direct and indirect jobs for aviation.

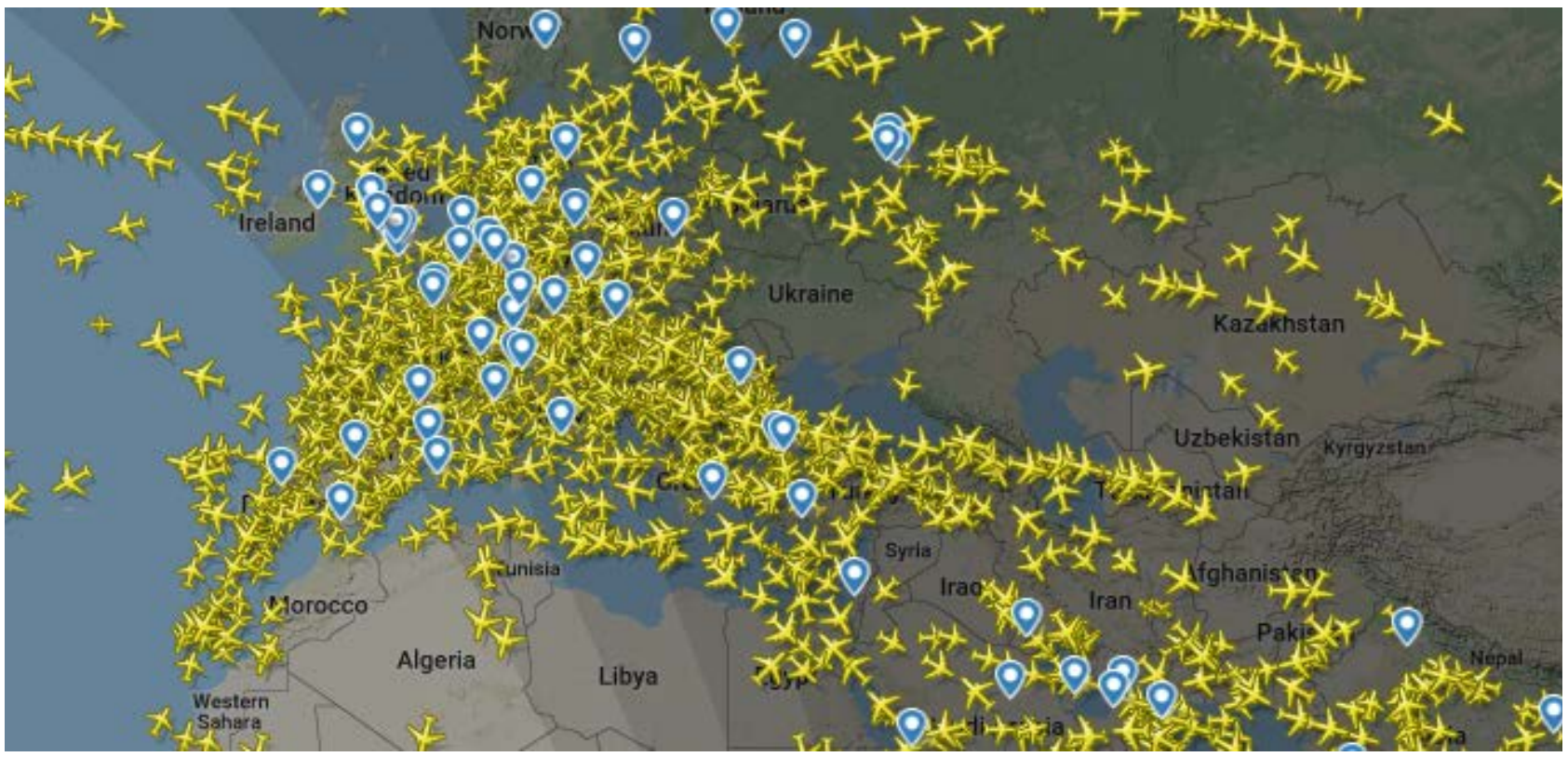

Figure 1. The number of flights in Ukraine and Europe 
However, in this area, there are still a lot of problematic issues, namely:

1. The lack of a clear airport development policy.

The development of airports is hampered by unfavorable tax policies. State airports transfer a significant share of revenues to the state budget, despite the fact that investment in certification and development is constantly required, and the cost of airport activities is quite high.

Inadequate government funding does not allow to develop the airport infra-structure in line with modern standards.

2. Slow harmonization of Ukrainian technical standards with EU standards.

Due to the lack of public funding, state institutions in the industry do not have time to implement a policy of adaptation of domestic norms and standards to EU legislation. Today in Ukraine, the civil aviation activity is governed by normative legal acts issued on the basis of the Soviet Union legislation, the documents of the International Civil Aviation Organization and some documents of the European Union developed in 1995-2000. For the period from 2000 to the present, the documents of the International Civil Aviation Organization and the European Union have been continuously improved.

Thus, Annex VI of the Chicago Convention on International Civil Aviation (1944), which regulates the standards of operation of civil aircraft in three parts, has been reissued more than eight times and today it contains more than ninety amendments.

3 . The lack of a clear plan for the liberalization of the passenger air transport market.

The aviation market of Ukraine has many opportunities to expand the volume of passenger and cargo flights. The advantage of the geographical location at the intersection of trade routes, which contain necessary conditions for the formation of a modern system of transport links in accordance with European standards, and the availability of international airports, is one of the attractive features of the national market of Ukraine for foreign investors and manufacturers. However, today air traffic is not a competitive market in Ukraine [3].

The issue of common aviation space acquired particular relevance after Ukraine received a visa-free regime with the EU. Now, in terms of facilitating the exit procedure, Ukrainians are more acutely experiencing a lack of competition among air carriers operating flights to EU countries.

The Ministry of Infrastructure and the Ministry of Foreign Affairs pursued negotiations on the status of the Gibraltar airport with the relevant EU departments and its member states for the early signing of the CAA Agreement during 2014-2016.

During this period, the following list of activities was carried out:

- In October 2014, Ukraine introduced a new version of the compromise wording of Article 2 (31) of the CAA Agreement on the Gibraltar Airport for consideration by the British side;

- The Ministry of Infrastructure together with the Ministry of Foreign Affairs and the State Aviation Administration prepared 5 alternative formulations of Article 2 (31) of the CAA Agreement, which can be acceptable to all parties, and initiated intergovernmental consultations;
- Ex-Minister of Infrastructure A.M. Pivovarsky with the Secretary of State for Foreign Affairs of Spain, Ambassador of the United Kingdom in Ukraine, Commissioner for Transport, Commissioner for Regional Policy and Director of the Department of Foreign Affairs of Russia, the Eastern Partnership, Central Asia, regional cooperation and the OSCE of the European External Action Service held meetings on the necessity of signing the Agreement on CAA in 2015-2016;

- The Minister of Infrastructure V.Omelyan held a working meeting on the signing of the CAA Agreement with the European Commissioner for Transport in September 2016.

Ukraine's accession to the European Common Aviation Area directly affects the interests of Ukrainian and EU airlines. European air carriers, such as Lufthansa, Austrian Airlines, LOT, WizzAir, Easy Jet, after the implementation of the Agreement will have unlimited commercial rights both for transport between points from Ukraine to the EU and between points inside Ukraine. At the same time, Ukrainian airlines will be able to expand their capabilities in the European aviation market.

The largest Ukrainian air carrier - UIA officially announced its support for the CAA Agreement. In 2015, the airline asked the European Commission to speed up the signing of the Agreement, which will improve the Ukraine`s aviation legislation and raise aviation standards, open up new market opportunities and bring economic benefits to both parties. At the same time, European Common Aviation Area can reduce UIA revenues as the Ukrainian market will become open for European low-cost bridges, which will create competition for the Ukrainian carrier. At the same time, UIA may face the problem of the lack of free time slots at popular European airports and will not allow transportation between EU member states.

The implementation of the CAA Agreement also directly concerns the interests of Ukrainian airports, since competition between them will definitely increase. The implementation of the Agreement will stimulate the development of the transit potential of the Boryspil International Airport, and will increase the efficiency of using other airports, in particular Kiev-Zhuliany, Odessa International Airport and Lviv International Airport, which will be able to offer their services for European low-cost carriers.

However, the "Open Skies" regime will truly work when Ukrainians are financially able to afford to visit any European country. Therefore, changes to the Air Code of Ukraine would be very relevant, namely:

- supplementing the Air Code of Ukraine with provisions prohibiting state and local authorities from adopting acts that may lead to the prevention, restriction and distortion of competition in the air transport market;

- the exclusion from the Air Code of Ukraine of provisions restricting legal entities with foreign capital in obtaining a license for air transportation;

- the exclusion from the Air Code of Ukraine of the provision, which allows the authorized body to refuse to grant the right to operate the corresponding airline (or limit this right) on such a basis as the need to achieve profitability [4]. 
In general, there are both external and internal problems that slow down or hinder the full liberalization of the aviation market with the EU.

Among internal problems the most acute are:

1. The lack of procedures for incorporation of the EU technical regulations provided for in the CAA Agreement and the lack of interest of relevant departments in the prompt incorporation of relevant legislation.

2. High prices for aviation fuel.

3. Lack of modern rules for market entry and certification of ground handling services at Ukrainian airports in accordance with EU standards.

External factors include:

1. The problem of the expected exit of the UK from the EU.

2. The lack of interest of European airlines in the Ukrainian market due to the low financial capacity of Ukrainians and the presence of a powerful national air carrier "UIA".

3. EASA distrust to the certification system of national carriers in Ukraine by the State Aviation Administration [5].

Therefore, it would be advisable to offer alternatives to solve the above problems. To solve the problem of lack of progress in signing the Agreement on the Common Aviation Area and liberalization of the air transport market, the following alternatives are proposed:

Conclusions. Having substantiated the conducted research, it is possible to identify both positive and negative sides of Ukraine's accession to the "Open Skies".

Firstly, for airlines, after the conclusion of the Agreement on CAA, it becomes possible to carry out air transportation to all EU member states without restrictions and compete in the European space.
At the same time, there will be an increase in price competition in the market, an increase in the cost for ensuring safety standards, a decrease in air carrier profits due to lower prices for air tickets and through payment of compensation.

Secondly, due to the increase in investment flows for the development of air transport infrastructure, the possibilities of renewing and building new terminals are expanding, which will lead to an increase in the role of Ukraine as a transit state and renovation of regional airports and airfields, convenient for using low-cost charter flights. At the same time, airports may encounter certain difficulties, such as flights delays, due to the limited ability of their service and an increase in waiting time at the passport control station.

Thirdly, the use of the airspace of Ukraine in the air navigation services sector will definitely increase the revenue from fees. However, a clear problem in this area is the obsolescence of air navigation equipment, inadequate maintenance of flights over the airspace of Ukraine, and excessive loading may occur due to an increase in the number of flights.

Finally, the CAA Agreement will lead to ensuring European safety standards and European level of passenger service, increasing the number of flights and routes, and expanding the price range of air transportation services.

It may be concluded that the process of harmonization of national and pan-European standards and norms is time consuming, requires considerable effort as well as a large number of measures by the state, and this process manifests itself in both positive and negative consequences, which requires careful consideration and analysis.

\section{Alternatives for liberalization of the aviation market with the EU}

Table 1

\begin{tabular}{|c|c|}
\hline Alternative & Description \\
\hline $\begin{array}{l}\text { Increased political } \\
\text { pressure from } \\
\text { Ukraine regarding the } \\
\text { signing of the CAA } \\
\text { Agree-ment }\end{array}$ & $\begin{array}{l}\text { - Public advocacy of the signing of the CAA Agreement by the Ministry of Foreign } \\
\text { Affairs, the civil society of Ukraine and the EU member states, aimed at the European } \\
\text { Commission, the UK, Spain and the embassies of the EU member states; } \\
\text { - Development, submission and advocacy of new formula-tions of Article } 2 \text { (31) of the CAA } \\
\text { Agreement for the European Commission, the United Kingdom and Spain; } \\
\text { - Determination of the authorized person for the signing of the Agreement. }\end{array}$ \\
\hline $\begin{array}{l}\text { Changing the appr } \\
\text { to the negotiation } \\
\text { the signing of the } \\
\text { Agreement }\end{array}$ & $\begin{array}{l}\text { - Engaging in lobbying for the signing of the Agreement by the country's top leadership: } \\
\text { the President, the Prime Minister, the Vice Prime Minister for European Integration, } \\
\text { because the re-sources of the sectoral departments are almost exhausted. }\end{array}$ \\
\hline $\begin{array}{l}\text { Conduct negotiations } \\
\text { to bene-fit from the } \\
\text { CAA Agreement } \\
\text { without direct signing } \\
\text { of the Agreement }\end{array}$ & $\begin{array}{l}\text { - Strengthening active negotiations between Ukraine and the EU member states on the signing } \\
\text { of bilateral agreements on the airspace liberalization by involving independent experts and } \\
\text { repre-sentatives of civil society of Ukraine and EU member states in the negotiations; } \\
\text { - Providing publicity to the negotiations; } \\
\text { - Enhancing the image of Ukraine as an investment-attractive country through } \\
\text { investment activities, creating favorable conditions for starting and conducting business. }\end{array}$ \\
\hline $\begin{array}{l}\text { Focusing or } \\
\text { implementa- } \\
\text { the first stage } \\
\text { CAA Agree }\end{array}$ & $\begin{array}{l}\text { - Focusing on the implementation of the CAA Agreement in terms of EU technical } \\
\text { regulations and directives and waiting for the appropriate moment to resume active } \\
\text { negotiations on signing the Agreement; } \\
\text { - Organization of the signing of the Memorandum with the European Commission on the } \\
\text { convergence of certification systems; } \\
\text { - The incorporation into the national legislation of Ukraine of EU regulations and } \\
\text { directives specified in Section } 2 \text { of Annex III of the CAA Agreement; } \\
\text { - Simplification of the procedure of the Ministry of Justice on the harmonization of } \\
\text { regulatory acts, which will allow to adopt EU regulations and directives in a package and } \\
\text { without long-term adaptation; } \\
\text { - Separation of areas of responsibility of the Ministry of In-frastructure and the State } \\
\text { Aviation Administration in the process of incorporating EU legislation. }\end{array}$ \\
\hline
\end{tabular}




\section{References:}

1. Dobidovska Ya.O. (2005). Ukraine-European Union Action Plan: Legal Aspects of Air Transport Change. TG Shevchenko Kyiv National University, Institute of International Relations.

2. Transport strategy of Ukraine for the period till 2030. Available at: http://www.mintrans.gov.ua

3. Milyan O.S. (2013). Compliance of national aspects of regulation in the civil aviation system with European standards in the context of the con-clusion of the Agreement on the Common Aviation Area. Available at: http://www.rusnauka.com/8_NMIV_2013/Economics/2_131591.doc.htm

4. EXPLANATORY NOTE to the Draft Law of Ukraine "On Amendments to the Air Code of Ukraine (Concerning the Prevention of Restrictions on Competition in the Field of Air Transport). Available at: http://search.ligazakon.ual l_doc2.nsf/link1/GH1XJ00A.html

5. Gudyma R.R. (2010). Common aviation space between Ukraine and the EU: positive and negative sides. Available at: http://www.rusnauka.com/27_NII_2010/Economics/72167.doc.htm 